\title{
Legibilidade e leiturabilidade: a correlação entre leitura e escrita a partir de opiniões de professores do ensino fundamental
}

\author{
Legibility and readability: the correlation between reading and writing from the \\ opinions of primary school teachers
}

Daniel Alvares Lourenço, Solange G. Coutinho

legibilidade, leiturabilidade, leitura e escrita

Este artigo tem como objetivo apontar e discutir a opinião dos professores do primeiro e segundo ano do ensino fundamental a partir de questionários qualitativos em relação ao processo de ensino da leitura e da escrita. Foi realizada uma revisão bibliográfica sobre o assunto. Além disso, foram inseridas considerações importantes relacionando leitura e escrita. Percebeu-se que os professores tem muito a contribuir na pesquisa e que são essenciais para se ter mais conhecimento sobre a aquisição da leitura referente aos leitores iniciantes. Além disso, notou-se a importância de se considerar aspectos do ensino da escrita em pesquisas envolvendo legibilidade e leiturabilidade.

legibility, readibility, reading and writing

The aim of this article is to describe and discuss the opinions of first and second year elementary school teachers regarding the processes involved in teaching reading and writing, using qualitative questionnaires. A literature review was conducted about the subject. In addition to this, important considerations were also included relating reading and writing. It was observed that teachers have much to contribute to research, and are essential when seeking to obtain greater knowledge of reading acquisition in beginning readers. Furthermore, we also realized how important it is to consider aspects regarding the teaching of writing in research involving legibility and readability.

\section{Introdução}

Este artigo tem como premissa uma pesquisa de âmbito maior que visa elaborar um

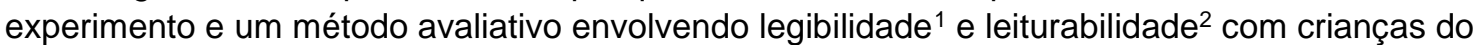
primeiro e segundo ano de escolas municipais públicas da cidade de João Pessoa e Cabedelo.

\footnotetext{
${ }^{1}$ Quando se trata de legibilidade, Sassoon \& Willians (2000) apontam que para as crianças devem-se considerar as diferentes necessidades desses leitores, ou seja, deve-se levar em consideração o espaçamento das palavras e justificar um texto somente se for necessário.

${ }^{2}$ Frascara (2003) aponta que leiturabilidade é diferente de legibilidade já que se "preocupa" com a compreensão dos textos. Aponta também que leiturabilidade, mais do que relacionado à percepção está relacionado à cognição. Cada 
Mesmo com os estudos acerca da fundamentação teórica relacionando os assuntos sobre legibilidade e leiturabilidade, é de fundamental importância a observação e a vivência do pesquisador com o pesquisado, neste caso as crianças.

De início, foi necessária a vivência em sala de aula com as crianças, para examinar o modo como as informações são apresentadas e transmitidas a elas, além de observar o comportamento e a opinião dos professores.

Outro aspecto a se considerar além da leitura é a escrita. Na escola, leitura e escrita, especialmente nas séries iniciais, se configuram como ações indissociáveis. Conforme progride a escolaridade, leitura e escrita vão sendo exploradas, desenvolvidas de forma mais individualizada ou inter-relacionadas por força de constantes operações, de via de mão dupla, que vão 'do ler para escrever' e 'do escrever para ler' e assim sucessivamente (Rocco, 1996: 116).

Portanto, parte-se do pressuposto que testes envolvendo legibilidade e leiturabilidade com leitores iniciantes não podem focar unicamente na leitura, mas, também deve se considerar a interação entre leitura e escrita para as crianças.

Sendo assim, o presente trabalho apresenta como objetivo apontar e discutir a opinião dos professores do primeiro e segundo ano do ensino fundamental a partir de questionários qualitativos em relação ao processo de ensino da leitura e escrita.

\section{Letramento}

Letramento é o resultado da ação de ensinar e aprender as práticas sociais de leitura e escrita. É o estado ou condição que adquire um grupo social ou um indivíduo como consequência de ter-se apropriado da escrita e de suas práticas sociais (Cunha, 2003:126).

A perspectiva do letramento é uma estratégia que pode dar sentido a (res)significação social das funções da escola, para que promova uma aprendizagem com significação e a interação do sujeito com as diversas leituras do cotidiano.

\subsection{Leitura e/ suas relações com a escrita}

Existem muitos aspectos sobre o processo da competência em leitura, dentre eles, envolve um conjunto de habilidades que incluem, entre outras, a capacidade do leitor criar suas próprias estratégias de compreensão, adequando-as às características do texto, construir significado, identificar a macroestrutura, a microestrutura e a superestrutura do texto, estabelecer uma rede de relações entre enunciados, organizando as informações que compõem as diferentes partes do material, realizar inferências, localizar informações relevantes, avaliar a informação recebida e utilizar adequadamente a informação (Brandão \& Spinillo, 1998).

Para as crianças, a leitura é interpretada como "olhar", enquanto se exige "falar" ou "dizer" para julgar um ato como leitura (Ferreiro \& Teberosky 1999: 168/169). Apesar da leitura e a escrita estarem inteiramente relacionadas, ela é na verdade a antítese da escrita. Na realidade cada uma atua em pontos distintos do cérebro. A escrita é uma habilidade, já a leitura é uma aptidão natural. (Fisher, 2006).

Portanto, para se realizar uma pesquisa e um método avaliativo envolvendo legibilidade e leiturabilidade, foi necessário desvendar as relações entre o aprendizado da leitura e da escrita. Sendo assim, a parte da pesquisa exploratória de maior importância se deu na abordagem metodológica com educadores do primeiro e segundo ano do ensino fundamental por meio de um questionário contendo perguntas abertas.

grupo de pessoas requer uma atenção, de crianças a idosos, todos, apresentam suas próprias maneiras de lidar com as informações apresentadas por escrito. 


\section{Metodologia}

\subsection{Elaboração dos questionários}

No início da pesquisa exploratória, buscou-se apoiar em todos os âmbitos escolares, ou seja, escolas particulares, estaduais e municipais. Para isso, foi oportuno realizar visitas nos três tipos de escolas e realizar uma investigação a partir de questionários com perguntas abertas.

Foram elaborados dois questionários: o primeiro para os professores do primeiro ano do ensino fundamental e o segundo para os professores do segundo ano. Vale ressaltar que os questionários foram entregues pessoalmente aos professores, para que pudessem ler $\mathrm{e}$ apontar qualquer dúvida imediata.

Adiante seguem as perguntas dos questionários. Vale ressaltar que apenas as perguntas de seis a onze é que apresentam diferenças de um questionário para o outro.

1. Qual a média de idade de seus alunos?

2. Que tipo de leitura seus alunos realizam dentro de sala de aula? Existe algum tipo de leitura realizada fora de sala de aula? Se sim, qual?

3. Como é realizada a escolha dos livros para as crianças? Vocês possuem liberdade de escolha? Tanto das editoras, quanto dos livros?

4. Existe algum material preparado por você para a leitura com as crianças. Se sim, qual e por que a necessidade de preparar este material?

5. Em sua opinião, a letra utilizada no quadro causa algum tipo de influência na leitura realizada pelas crianças? Ex.: Você percebe que as crianças tendem a retratar o tipo de letra que você escreve no quadro, tais como: letra em caixa alta, em manuscrito ou esse tipo de situação não causa nenhuma interferência na maneira delas escreverem e consequentemente no ato da leitura realizada por elas?

6. Como é o processo de ensino da leitura para as crianças do primeiro ano? Elas aprendem a ler com que tipo/s de letra/s?

6. As crianças continuam em processo de aprendizagem de leitura no segundo ano? Existe algum tipo de mudança no tipo de letras apresentadas a elas?

7. Como funciona o processo da aquisição da aprendizagem da escrita? É diferente do da leitura? Existe relação entre os dois processos? Se sim, você poderia explicar como funciona?

7. Elas ainda estão em aquisição da aprendizagem da escrita? Existe relação entre os dois processos no segundo ano? Se sim, você poderia explicar como funciona?

8. Existe alguma mudança no processo de leitura da criança ao longo do primeiro ano do primeiro ciclo do ensino fundamental?

8. Existe alguma mudança no processo de leitura do primeiro para o segundo ano do primeiro ciclo? Se existir, qual/quais é/são as principais diferenças?

9. Existe algum tipo de dificuldade que você pode relatar em relação à leitura das crianças? Qual ou quais?

9. Existe algum tipo de dificuldade que você pode relatar em relação à leitura das crianças? Qual ou quais? (segundo ano)

10. Os alunos utilizam ou preferem algum tipo de letra? Essa preferência ou facilidade muda no decorrer do primeiro ano?

10. Os alunos utilizam ou preferem algum tipo de letra? Essa preferência ou facilidade muda no decorrer do primeiro para o segundo ano? 
11. Existe algum tipo de letra que você acha que facilita a leitura e consequentemente 0 entendimento dos textos apresentados às crianças?

11. Existe algum tipo de letra que você acha que facilita a leitura e consequentemente o entendimento dos textos apresentados às crianças do segundo ano?

\subsection{Visita exploratória nas escolas}

Com os questionários elaborados, procurou-se a tratar de quais escolas da cidade de João Pessoa e Cabedelo seriam visitadas. As escolas foram escolhidas aleatoriamente, em diferentes regiões da cidade de João Pessoa e Cabedelo, em bairros de diferentes classes sociais.

Das 29 escolas visitadas para a aplicação dos questionários, têm-se: dezenove escolas da rede municipal, cinco escolas da rede estadual e cinco escolas da rede privada. A diferença entre a quantidade de escolas visitadas das redes municipais, estaduais e privadas se deve ao fato da dificuldade de acesso a determinadas escolas.

Foram entregues seis questionários na rede estadual com apenas três respostas. Nas escolas de rede privada, obteve-se apenas duas respostas.

Como os resultados dos questionários aplicados nas escolas de ensino privado e estadual não foram satisfatórios, a pesquisa de campo se focou primordialmente nas escolas de ensino municipal. Foram entregues sessenta e sete questionários para professores do primeiro e segundo ano do ensino fundamental da rede municipal. Sendo que trinta e sete destes responderam os questionários.

\section{Análise dos questionários}

Adiante será realizada uma breve análise de cada pergunta separadamente. Foram gerados gráficos para facilitar o entendimento das respostas (figura 01 e 02).

Pergunta 1: Gráfico gerado a seguir.

Figura 01: Gráfico da pergunta um. (Fonte: Lourenço)

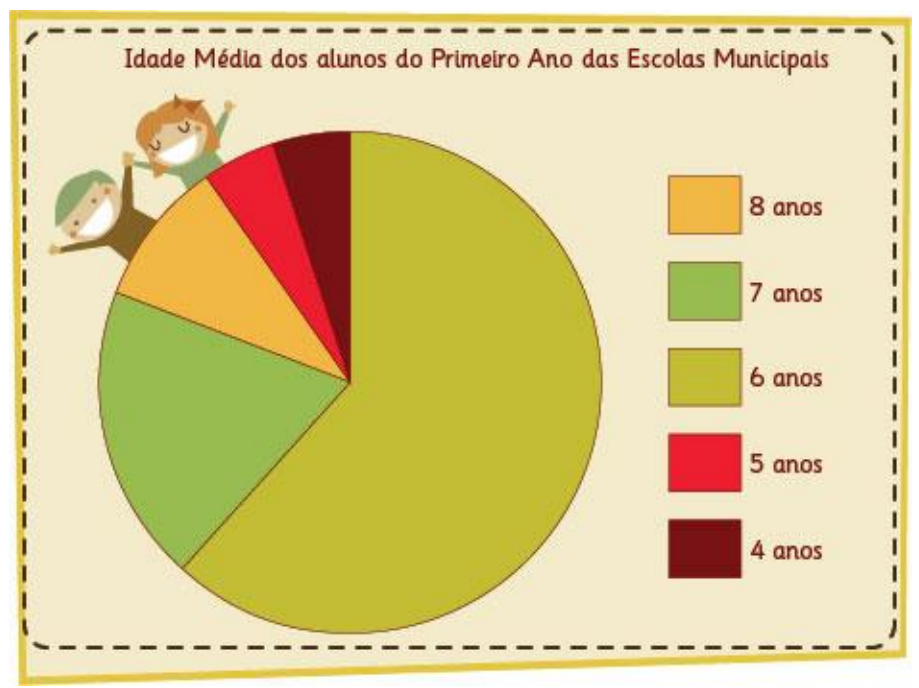


Figura 02: Gráfico da pergunta um. (Fonte: Lourenço)

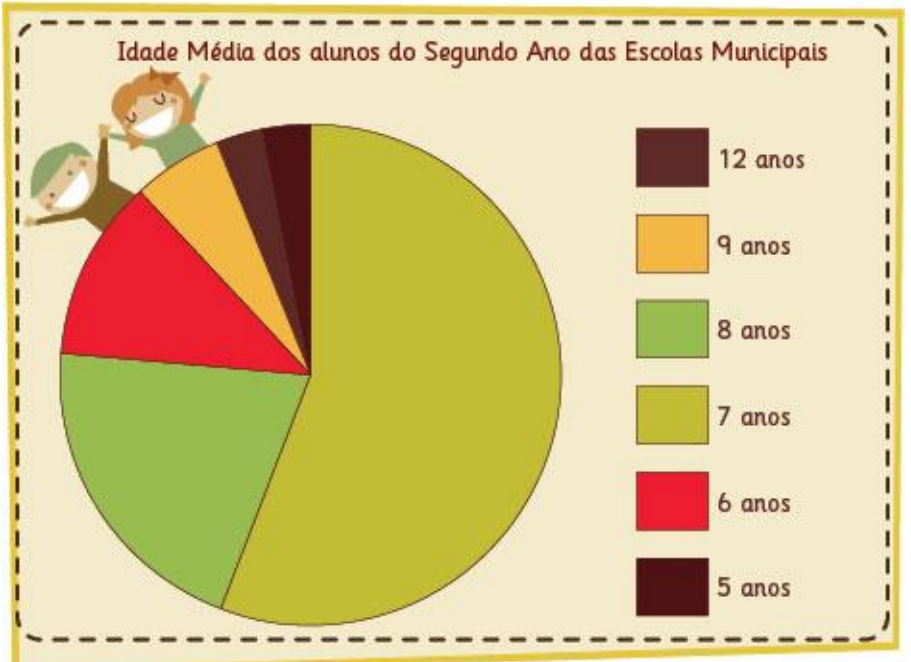

Pergunta 02: O gráfico (figura 03) é referente às respostas dos professores do primeiro ano.

Figura 03: Gráfico da pergunta dois. (Fonte: Lourenço)

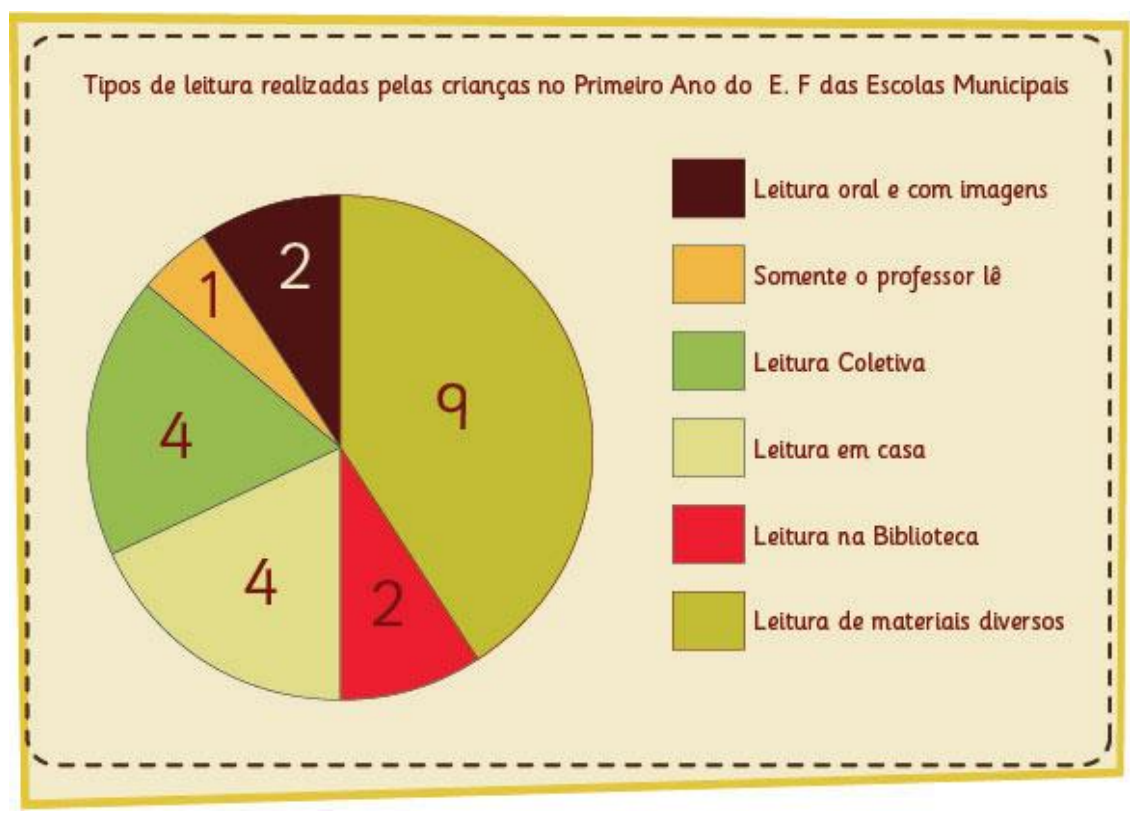

Já no segundo ano, tem-se o seguinte gráfico (figura 04): 
Figura 04: Gráfico da pergunta dois. (Fonte: Lourenço)

Tipos de leitura realizadas pelas crianças no Segundo Ano do E. F das Escolas Municipais

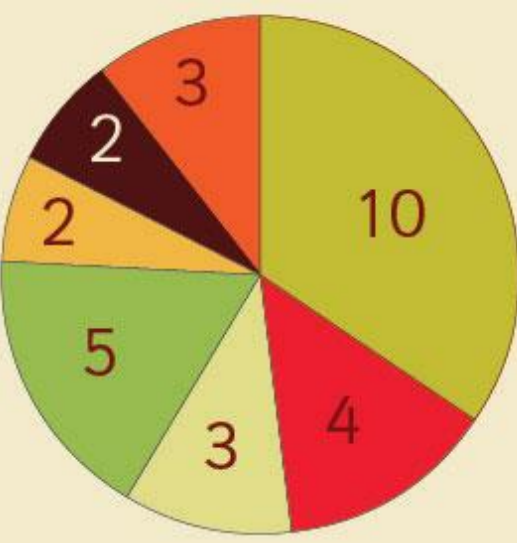

Leitura PNAIC (MEC)

Nao ocorre leitura em casa

Somente o professor lê

Leitura Coletiva

Leitura em casa

Leitura na Biblioteca

Leitura de materiais diversos

Percebe-se que no segundo ano a leitura de materiais diversos é o que mais ocorre. Alguns pesquisadores como Rosemary Sassoon (1993), Walker \& Reynolds (2003) destacam em seus experimentos com crianças a busca por materiais de leitura diversos, pois os testes se tornam mais familiares com a realidade das crianças.

\section{Pergunta 03: Segue o gráfico (figura 05).}

Figura 05: Gráfico da pergunta três, primeiro ano. (Fonte: Lourenço)

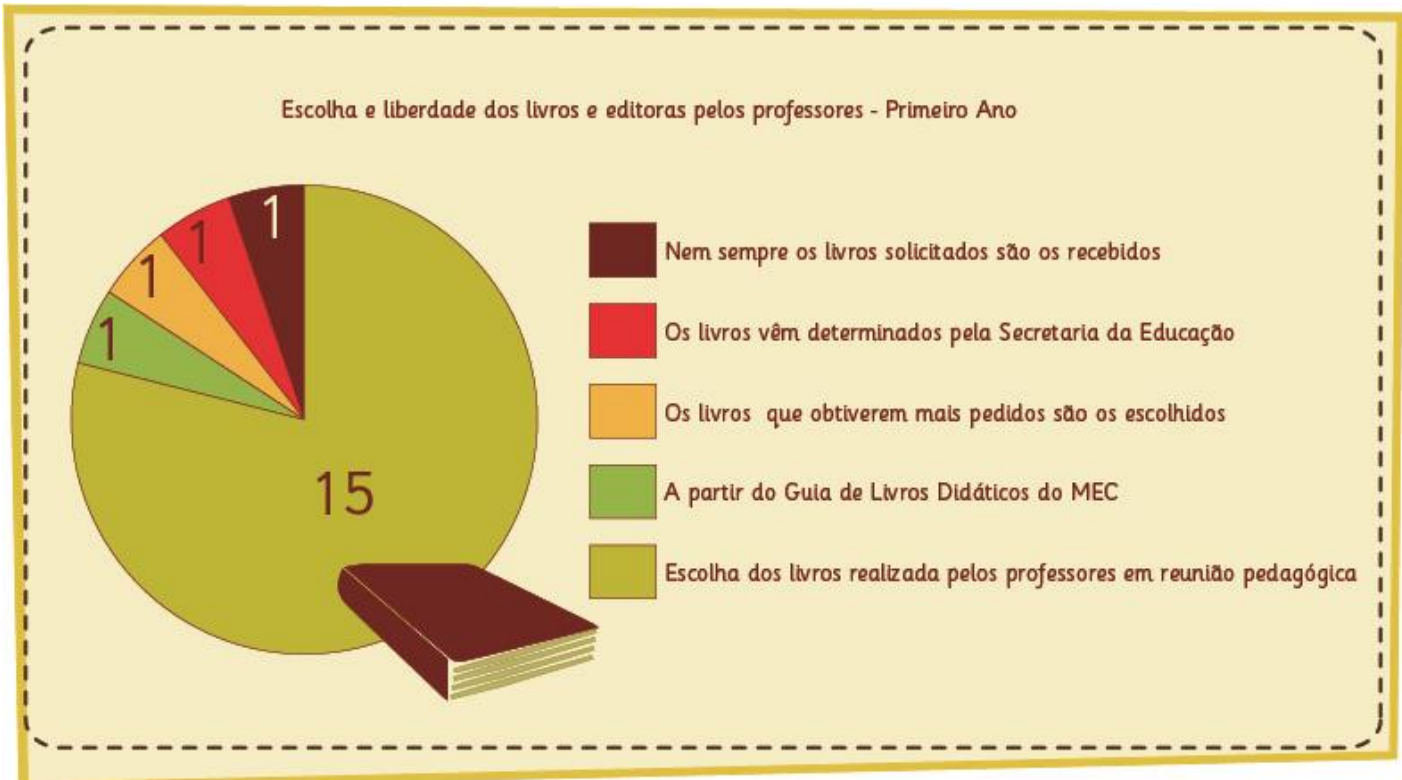


Pode-se perceber que a maior parte dos professores aponta para a liberdade de escolha dos livros e das editoras.

Já no segundo ano tem-se este resultado (figura 06):

Figura 06: Gráfico da pergunta três, segundo ano. (Fonte: Lourenço)

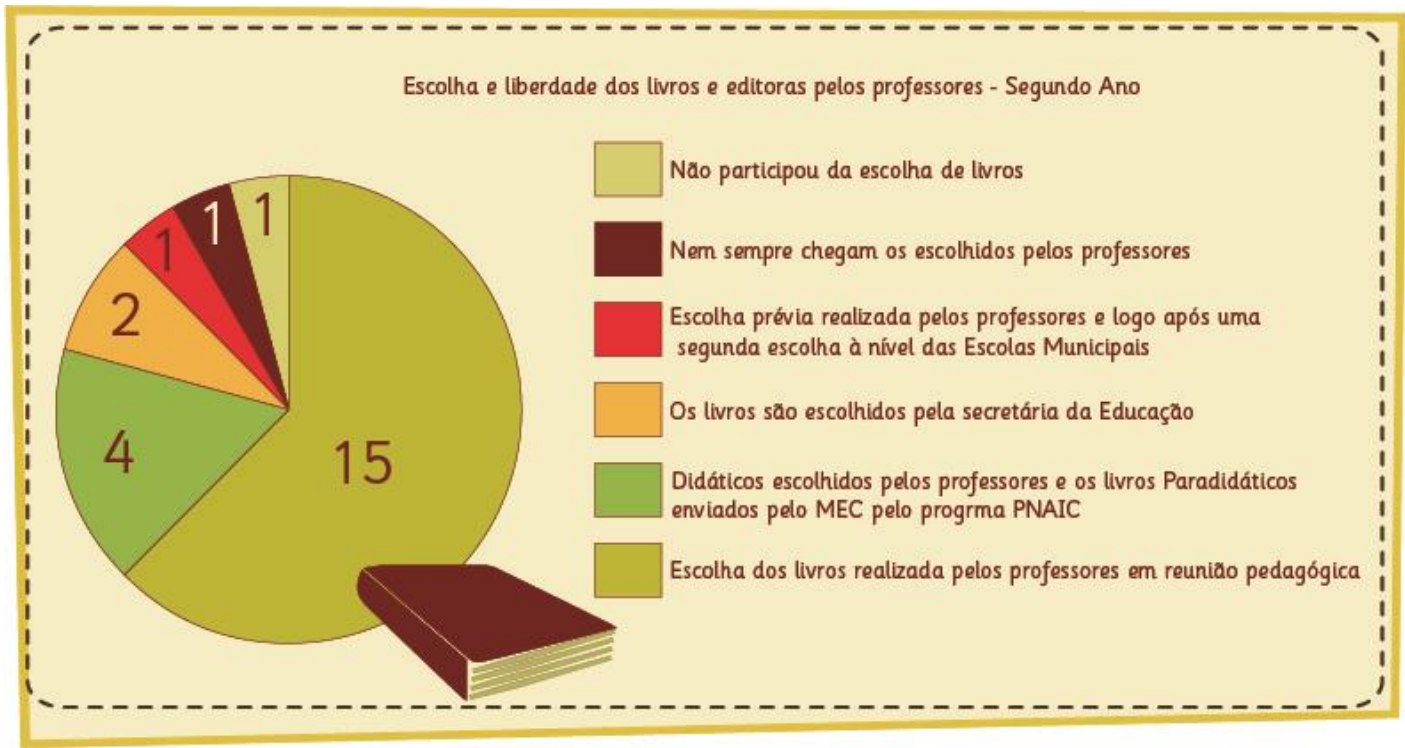

Pergunta 04: Os professores do primeiro ano obtiverem o seguinte gráfico (figura 07).

Figura 07: Gráfico da pergunta quatro, primeiro ano. (Fonte: Lourenço)

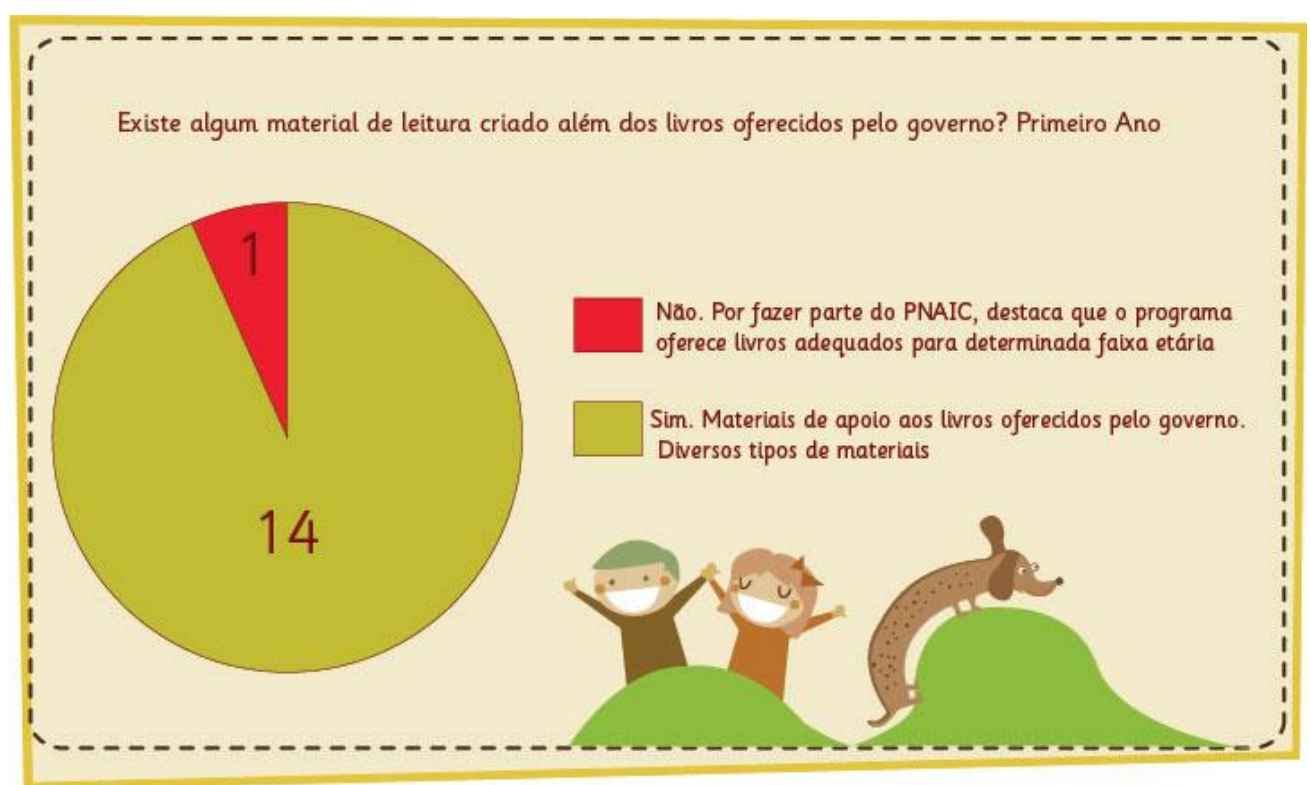

A seguir, o gráfico com as respostas dos professores do segundo ano (figura 08). 
Figura 08: Gráfico da pergunta quatro, segundo ano. (Fonte: Lourenço)

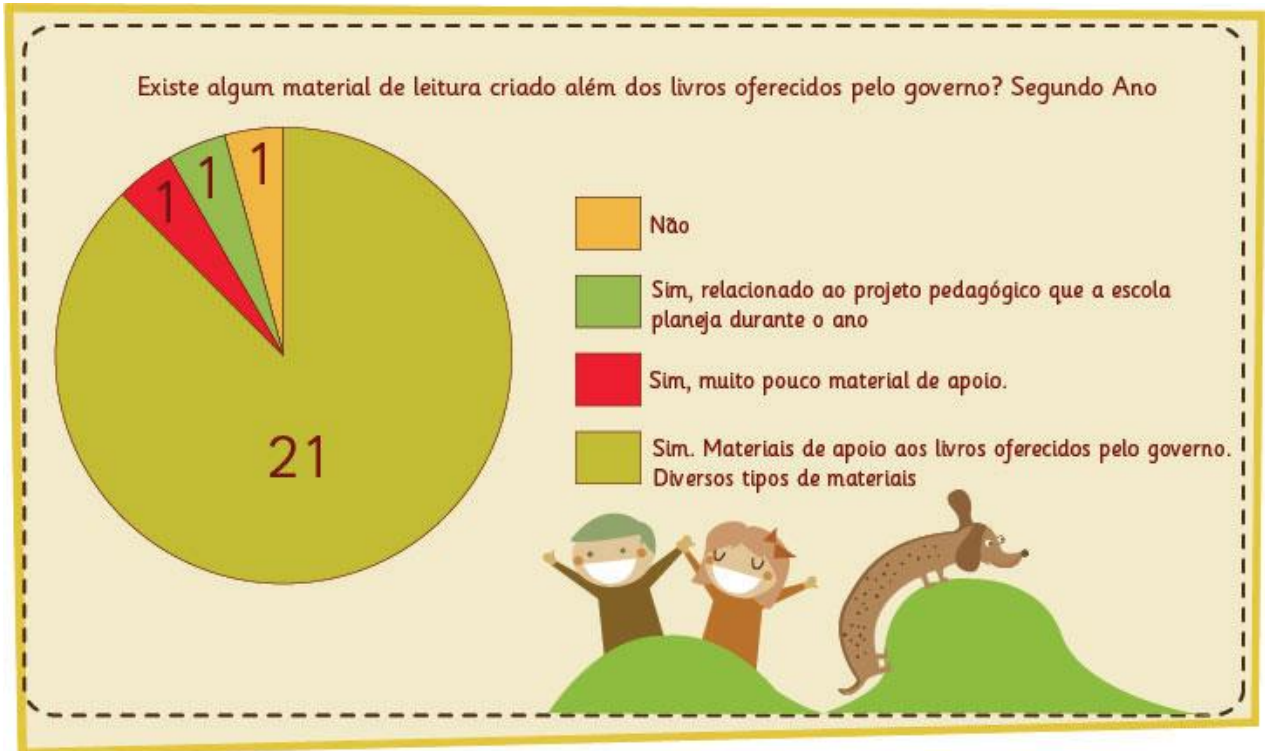

A maior parte dos professores destaca que produzem materiais além dos que chegam até as escolas, dentre eles, estão: livros de histórias infantis, cartilhas, cartazes, fichas de leitura, letras de músicas, lista de nomes, quadro da família silábica, rótulos, jogos educativos, poemas, adivinhações, materiais do PNAIC, textos da internet e folders.

Pergunta 05: Na quinta questão temos o seguinte (figura 09):

Figura 09: Gráfico da pergunta cinco, primeiro ano. (Fonte: Lourenço) 


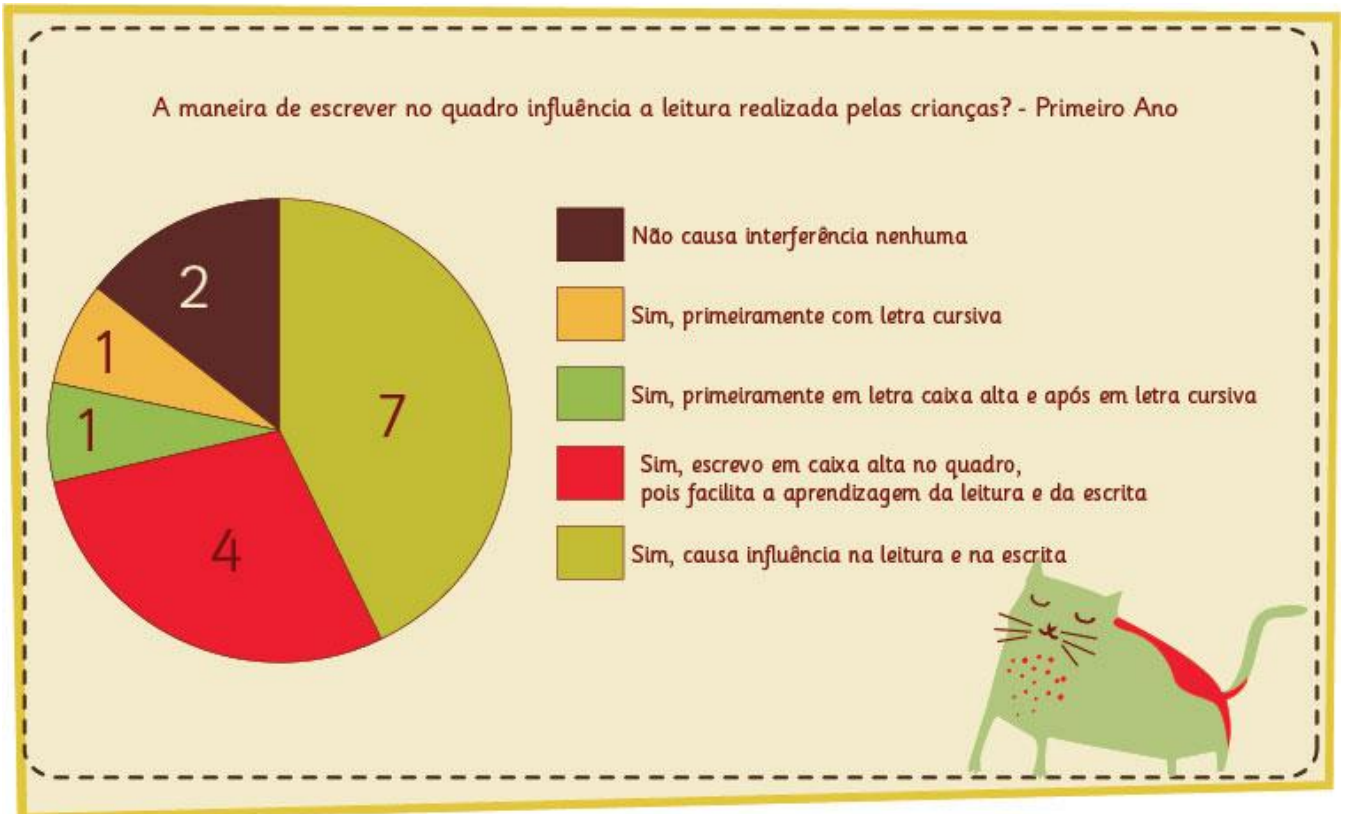

Em relação às respostas dos professores do segundo ano, tem-se (figura 10):

Figura 10: Gráfico da pergunta cinco, segundo ano. (Fonte: Lourenço)

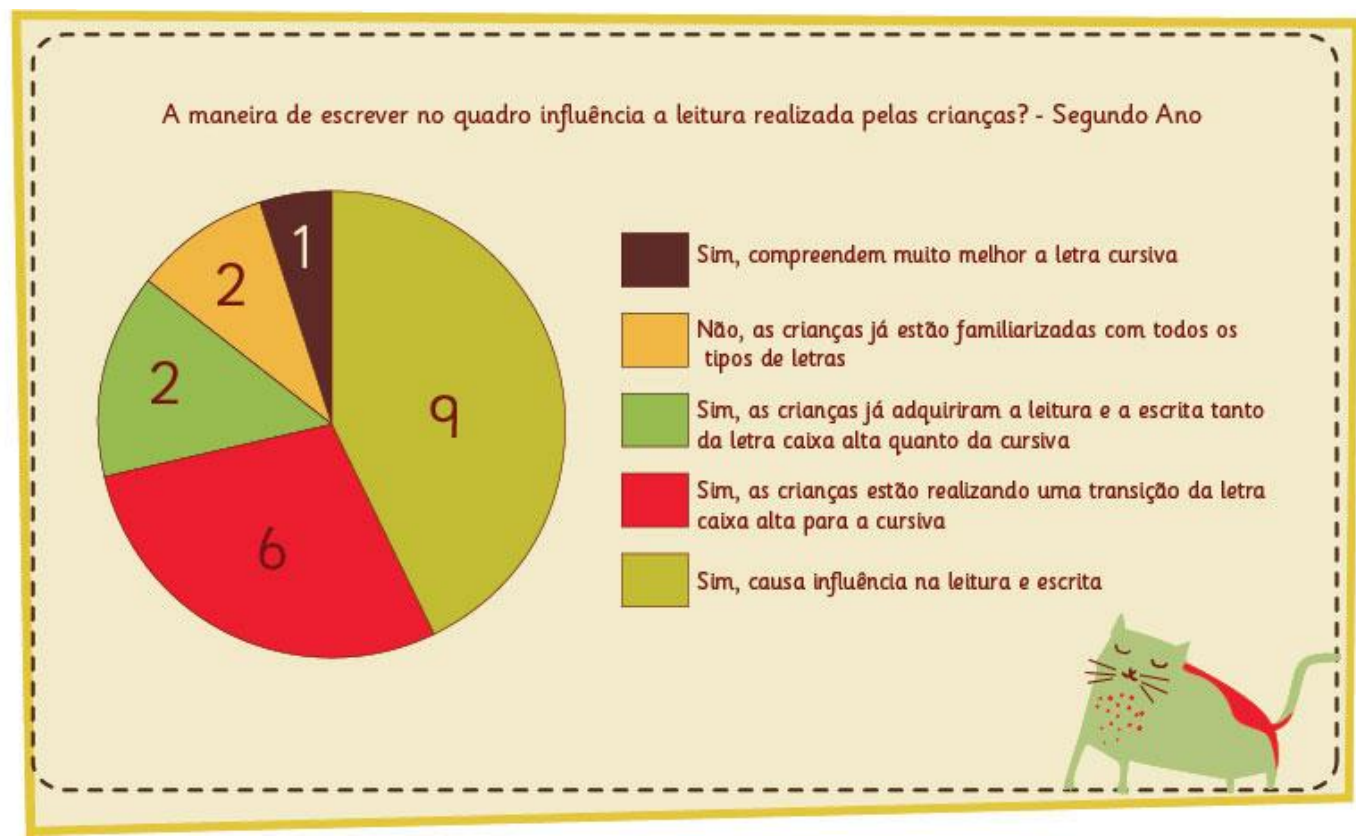

Pergunta 06 (primeiro ano): Gráfico gerado (figura 11).

Figura 11: Gráfico da pergunta seis, primeiro ano. (Fonte: Lourenço) 


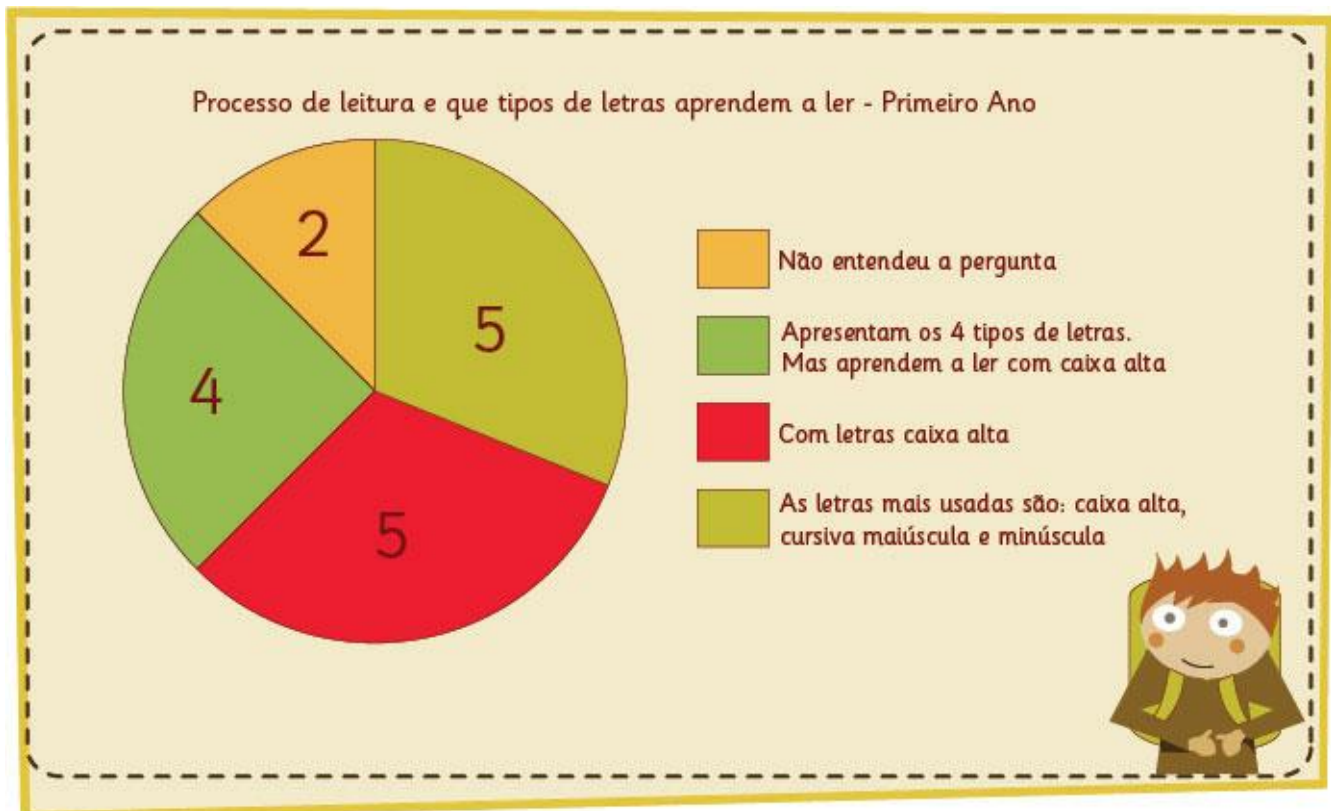

Pergunta 06 (segundo ano): já no segundo ano todos os professores afirmaram que as crianças continuam em processo de aprendizagem da leitura e da escrita, todavia em níveis diferenciados do primeiro ano (figura 12).

Figura 12: Gráfico da pergunta seis, segundo ano. (Fonte: Lourenço)

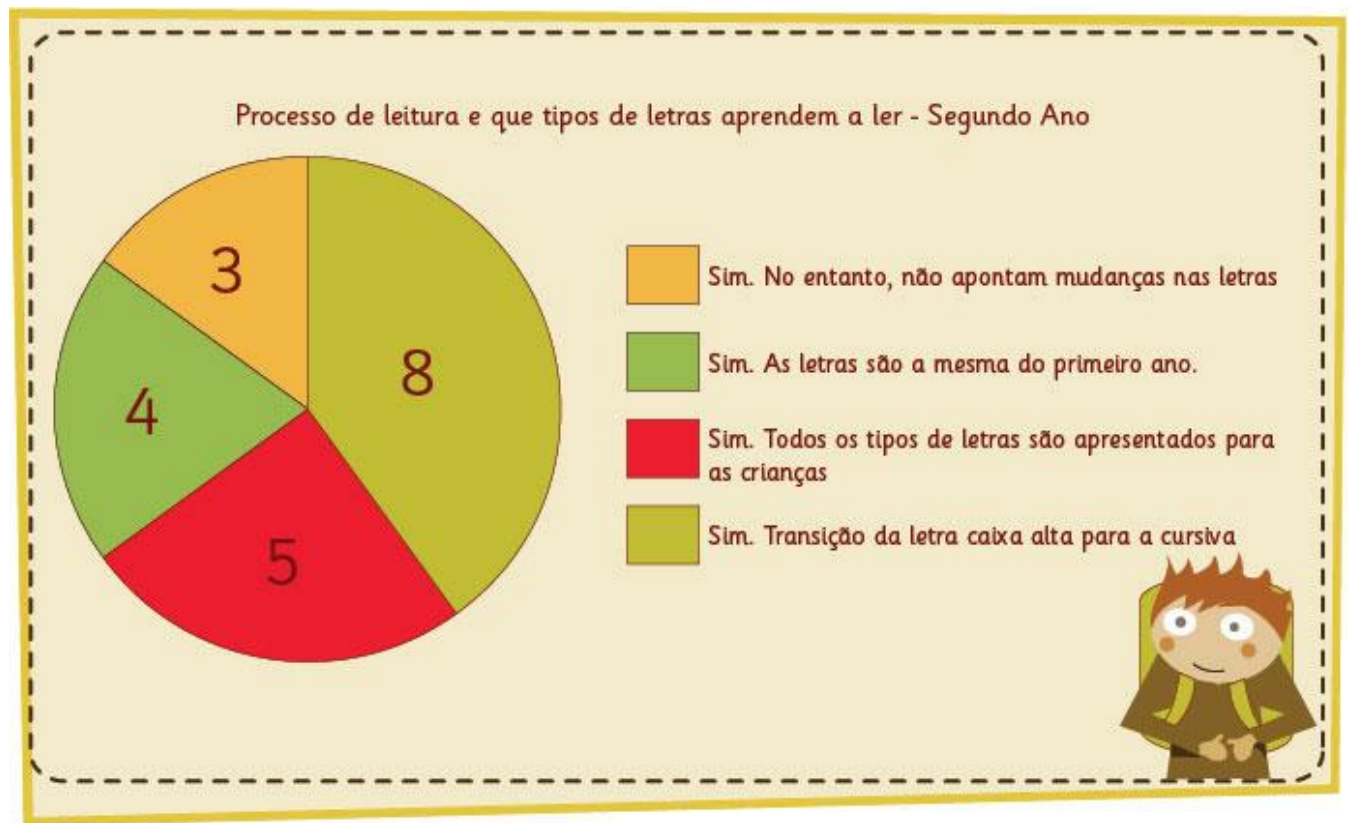

Um dos aspectos evidenciados com as respostas obtidas dos professores na sexta questão é que muitos deles analisam um dos fundamentos do PNAID - "(...) assegurar que todas as crianças estejam alfabetizadas até os oito anos de idade, ao final do $3^{\circ}$ ano do ensino fundamental" (PACTO/MEC, 2014) - de forma individual. 
Pergunta 07 (primeiro ano): A seguir o gráfico gerado com a questão sete (figura 13):

Figura 13: Gráfico da pergunta sete, primeiro ano. (Fonte: Lourenço)

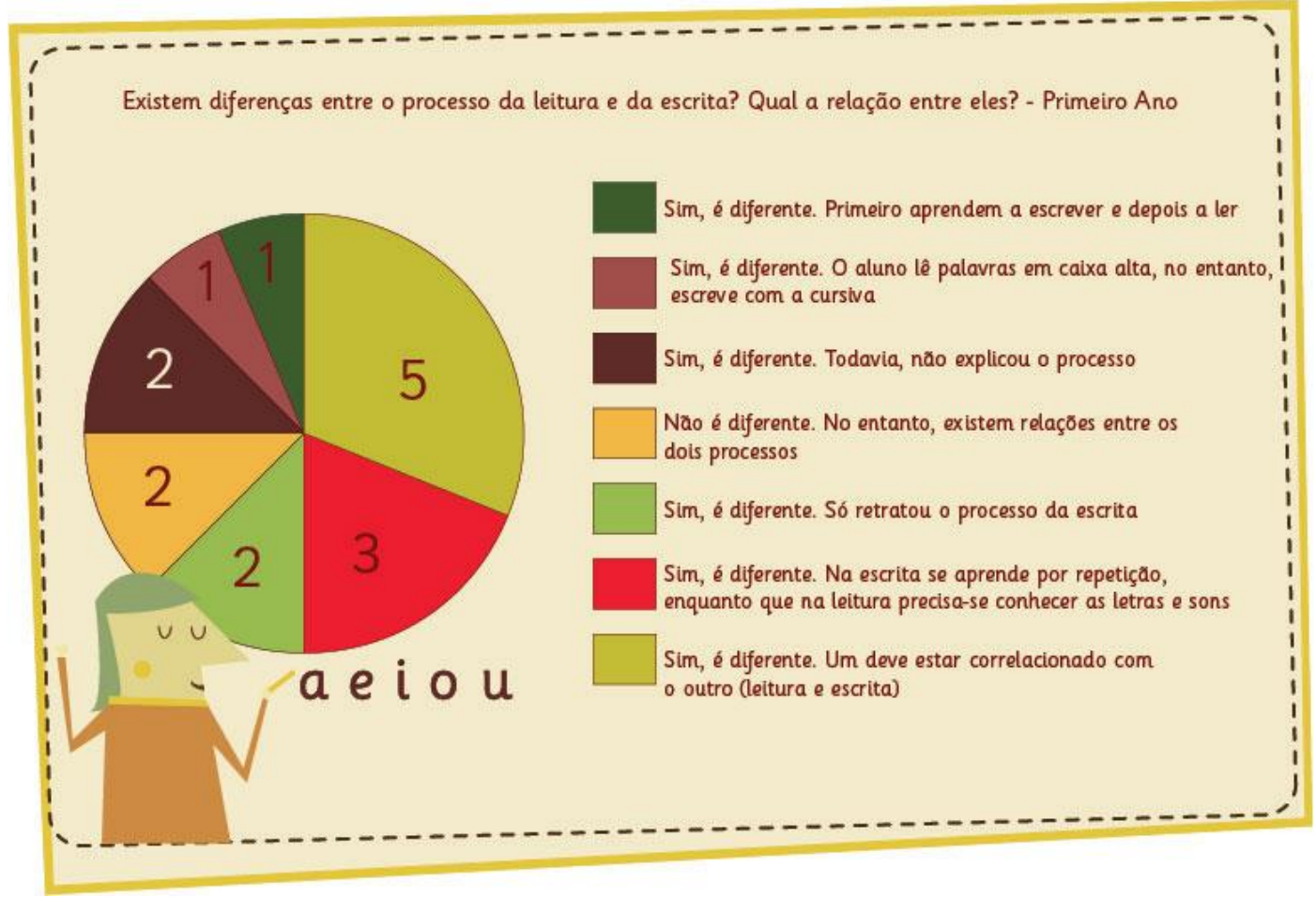

Pergunta 07 (segundo ano): Com as respostas dos professores do segundo ano, tem-se o seguinte gráfico (figura 14):

Figura 14: Gráfico da pergunta sete, segundo ano. (Fonte: Lourenço)

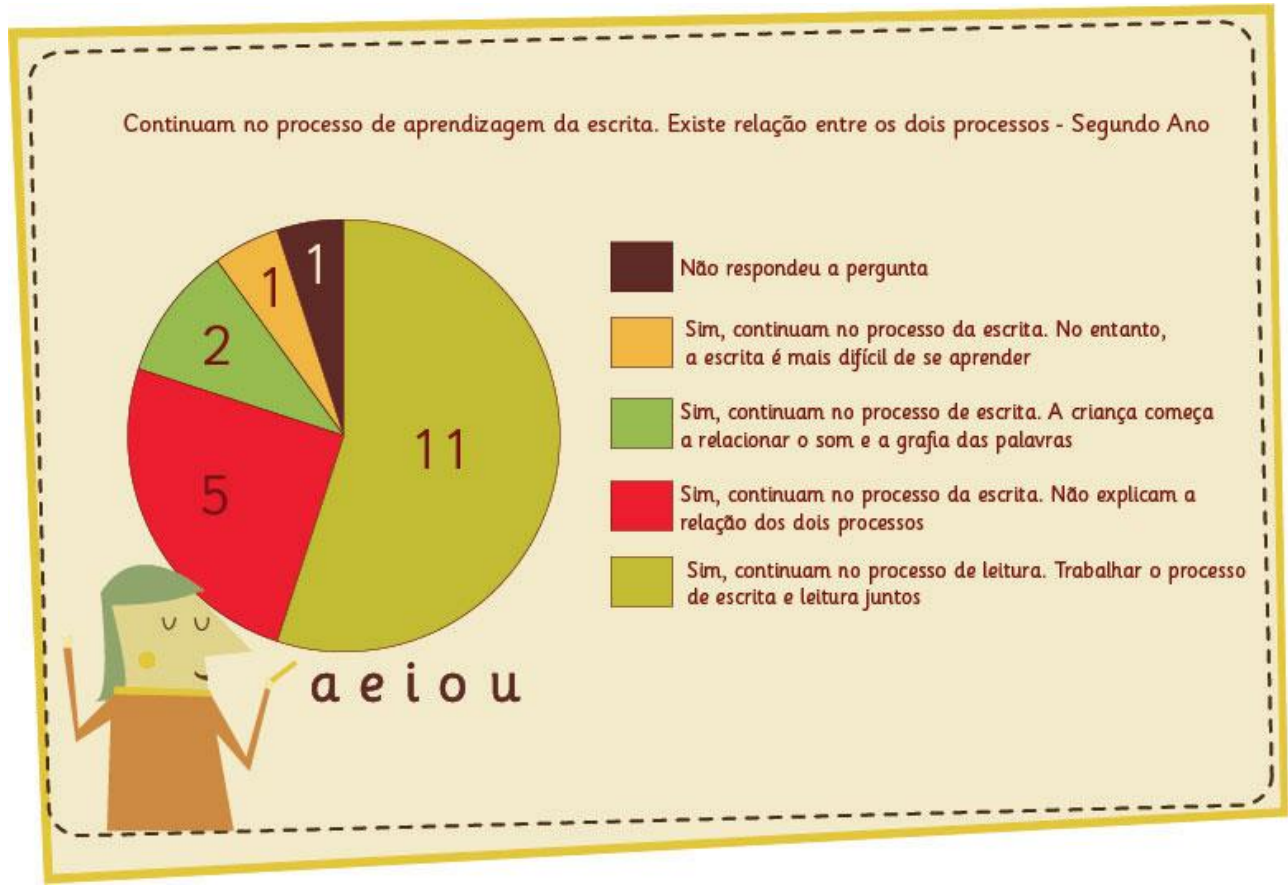


Todos os professores atestam para o fato dos alunos continuarem em aprendizagem de leitura no segundo ano do ensino fundamental. Destes, onze declaram que o processo da escrita e leitura continua junto.

Pergunta 08 (primeiro ano): gráfico gerado (figura 15):

Figura 15: Gráfico da pergunta oito, primeiro ano. (Fonte: Lourenço)

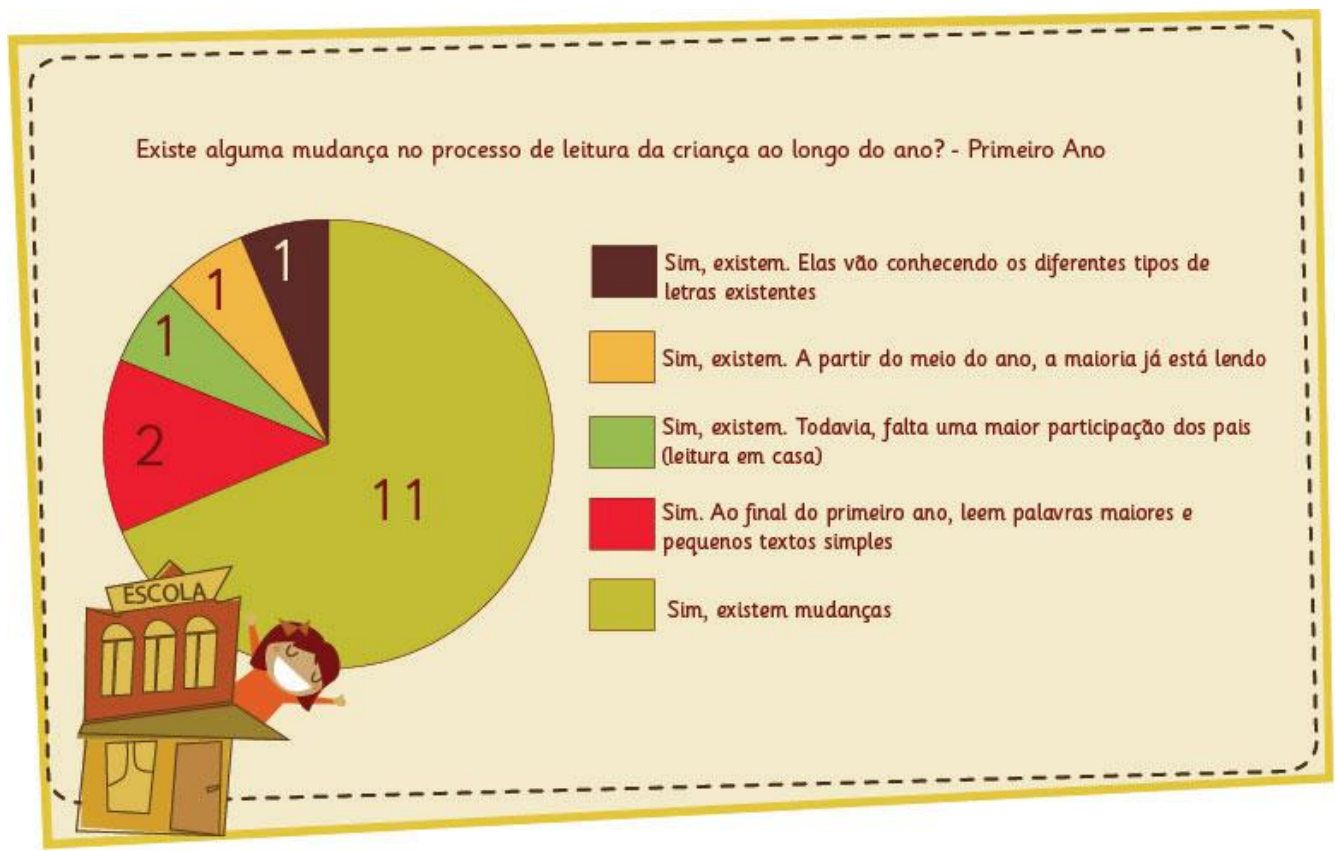

Todos os professores indicaram que existem mudanças no processo de leitura no decorrer do primeiro ano do ensino fundamental.

Pergunta 08 (segundo ano): Gráfico gerado (figura 16).

Figura 16: Gráfico da pergunta oito, segundo ano. (Fonte: Lourenço)

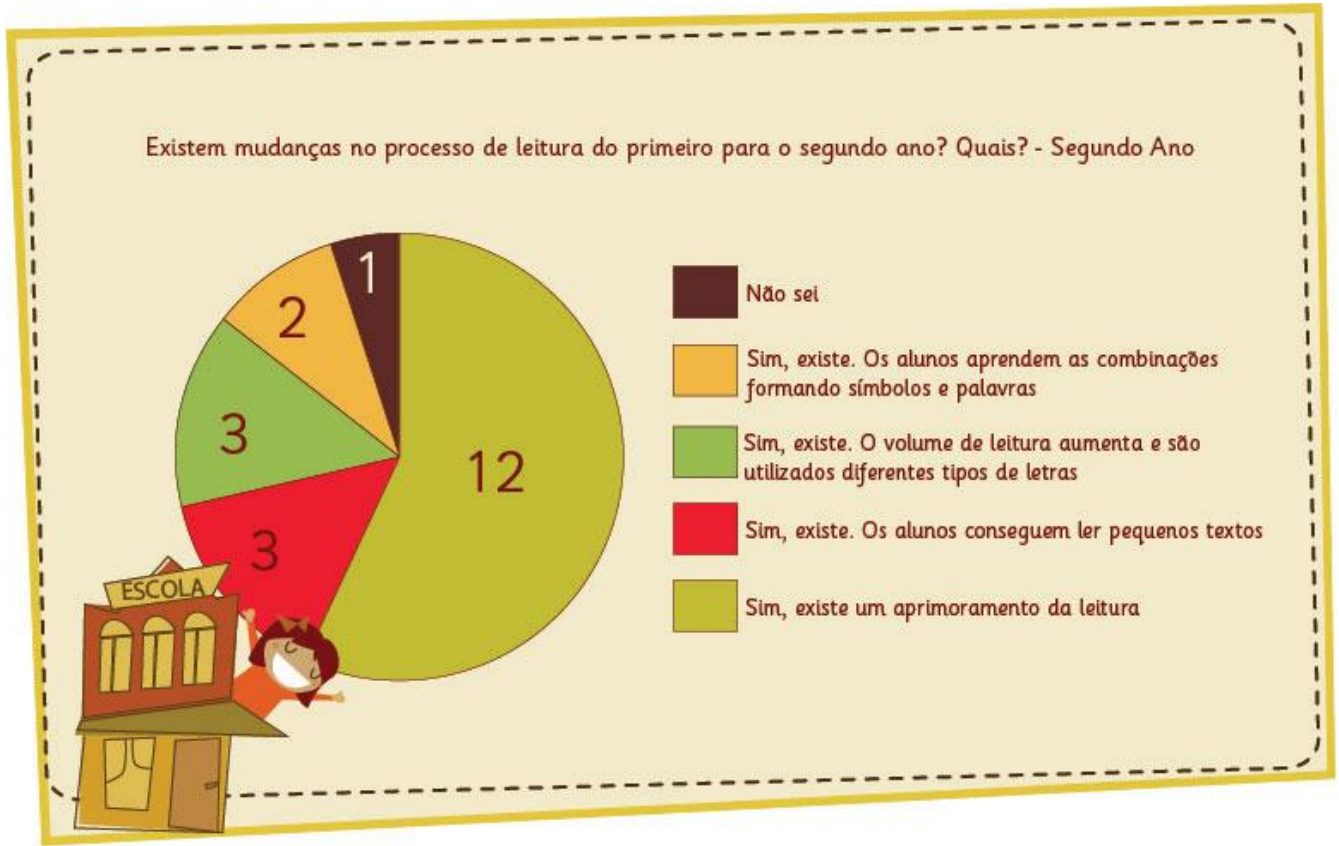


Sobre a passagem do primeiro para o segundo ano os professores destacam que existem mudanças no processo de leitura. A maior parte acrescenta que as crianças passam por um aprimoramento do ato de ler.

Pergunta 09 (primeiro ano): Sobre as dificuldades existentes sobre o processo de leitura ao longo do primeiro ano, foi gerado o seguinte gráfico (figura 17):

Figura 17: Gráfico da pergunta nove, primeiro ano. (Fonte: Lourenço)

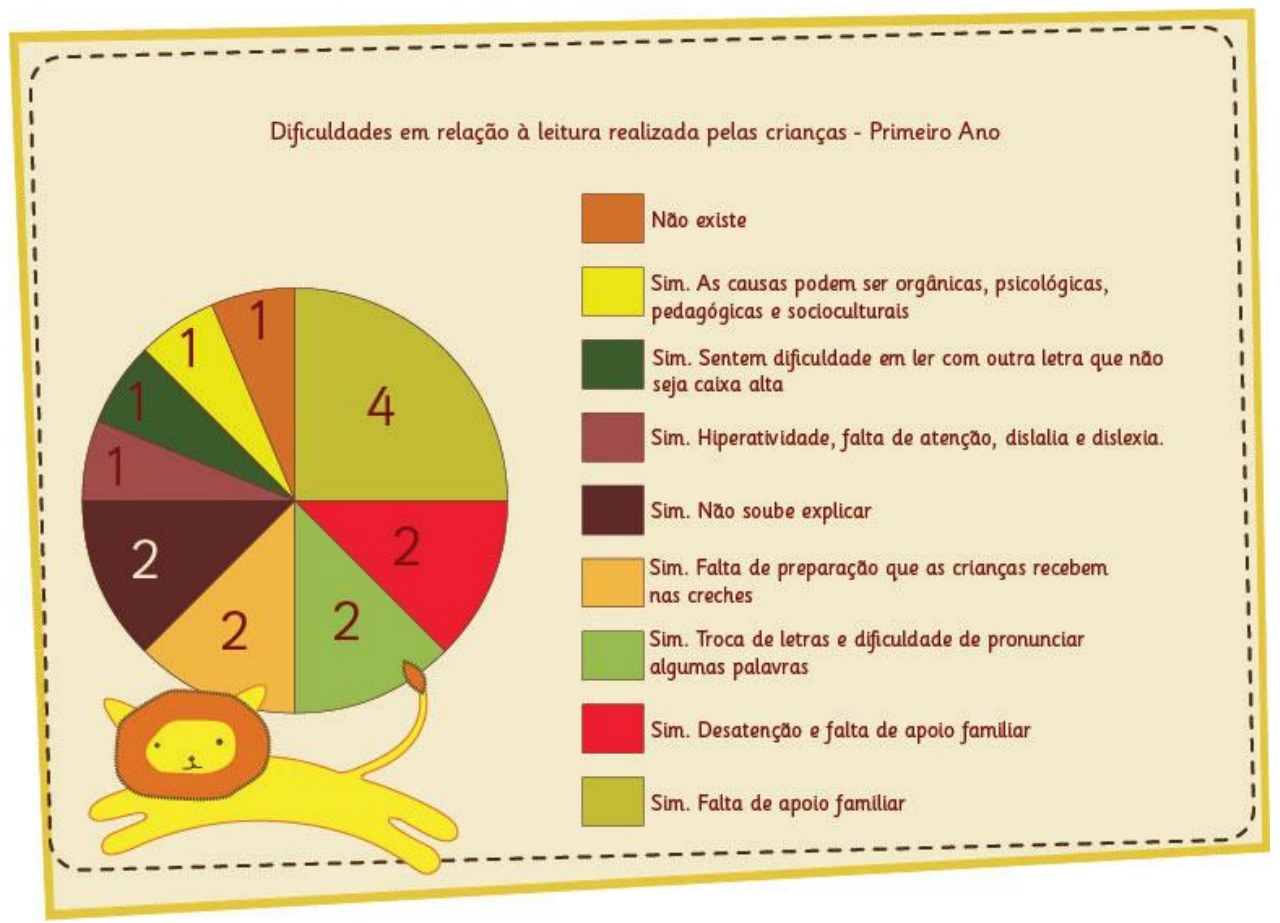

Apesar de somente uma das opiniões apontar que não existem dificuldades no processo de leitura das crianças e o restante dos professores destacarem diversas dificuldades, apenas dois citam aspectos relacionados à área tipográfica.

Pergunta 09 (segundo ano): Somente um dos professores do segundo ano nega o fato de não existir dificuldades da leitura realizada pelas crianças. Uma parte das opiniões (sete no total) destaca para a dificuldade que as crianças apresentam no reconhecimento de determinadas letras. (figura 18).

Figura 18: Gráfico da pergunta nove, segundo ano. (Fonte: Lourenço) 
Dificuldades em relação à leitura realizada pelas crianças - Segundo Ano
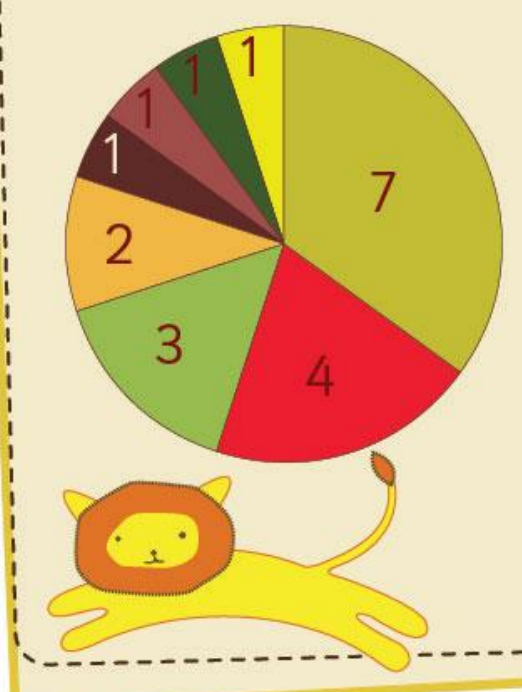

Nao existe

Sim. Existem alunos que são desestimulados

Sim. Dificuldades em fluência de leitura, correspondência som-ortografia, ortografia e compreensão textual

Sim. Não conseguem fazer a transiçăo das letras caixa alta para a cursiva

Sim. Dificuldades em fonemas e palavras complexas

Sim. A falta de concentraçăo

Sim. A falta de apoio familiar

Sim. Dificuldade do reconhecimento das letras

Pergunta 10 (primeiro ano): Segue o gráfico (figura 19).

Figura 19: Gráfico da pergunta dez, primeiro ano. (Fonte: Lourenço)

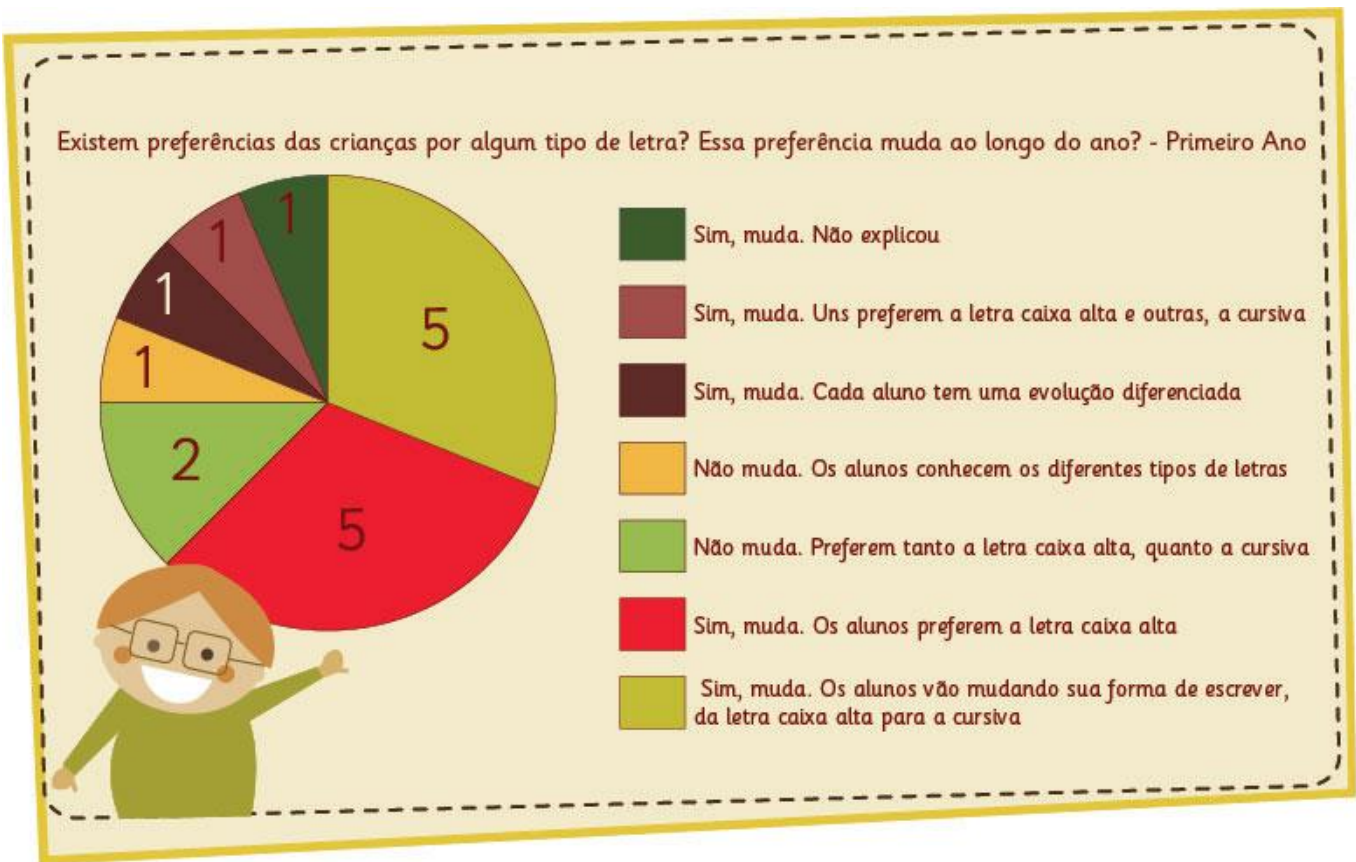

De todos os professores, apenas três apontaram que não existe uma mudança de preferência por determinado tipo de letra no decorrer do primeiro ano.

Pergunta 10 (segundo ano): Todos os professores do segundo ano afirmam que existe preferência de determinadas letras pelas crianças (figura 20).

Figura 20: Gráfico da pergunta dez, segundo ano. (Fonte: Lourenço) 


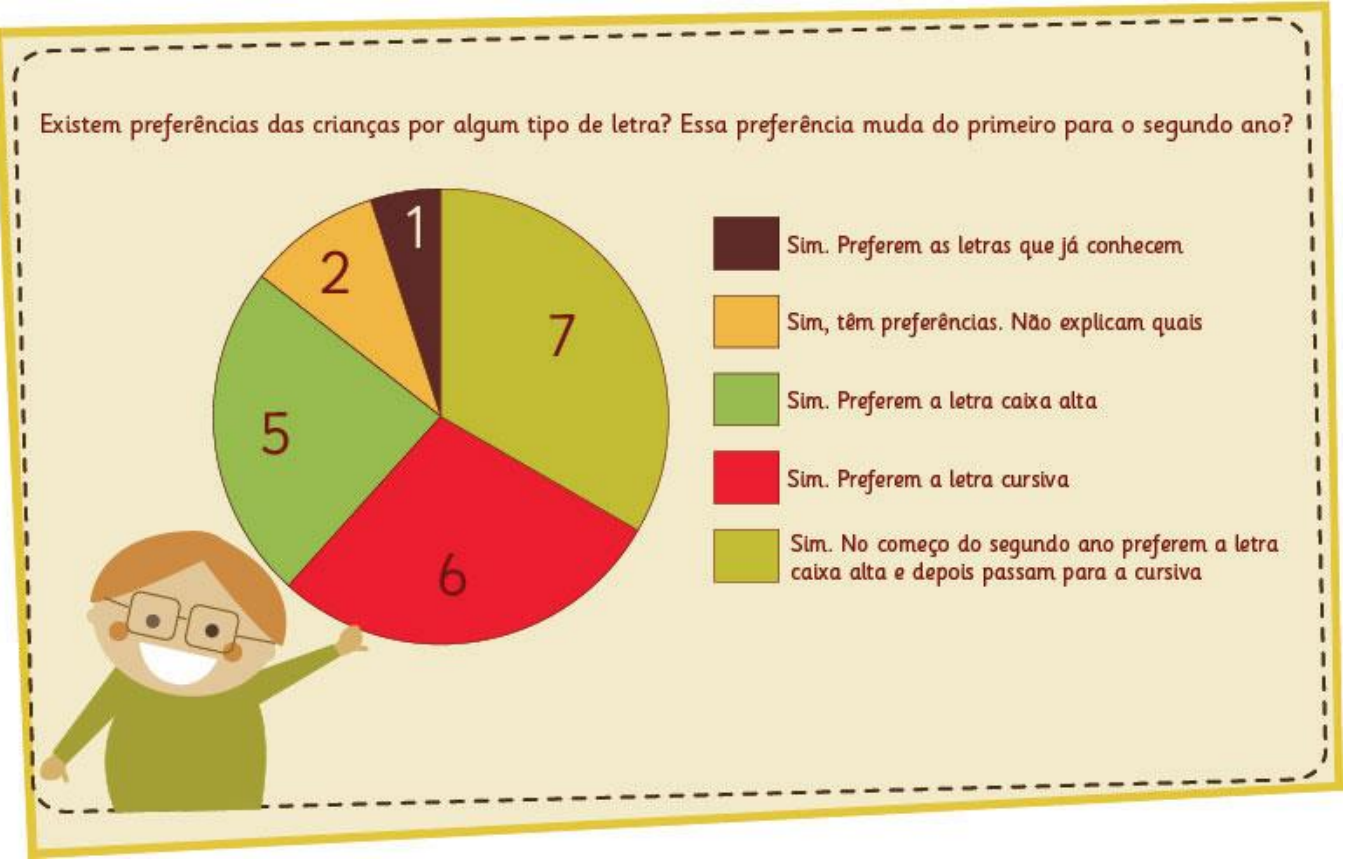

Pergunta 11 (primeiro ano): Em relação à preferência das crianças por determinado tio de letra para leitura, tem-se o seguinte gráfico (figura 21):

Figura 21: Gráfico da pergunta onze, primeiro ano. (Fonte: Lourenço)

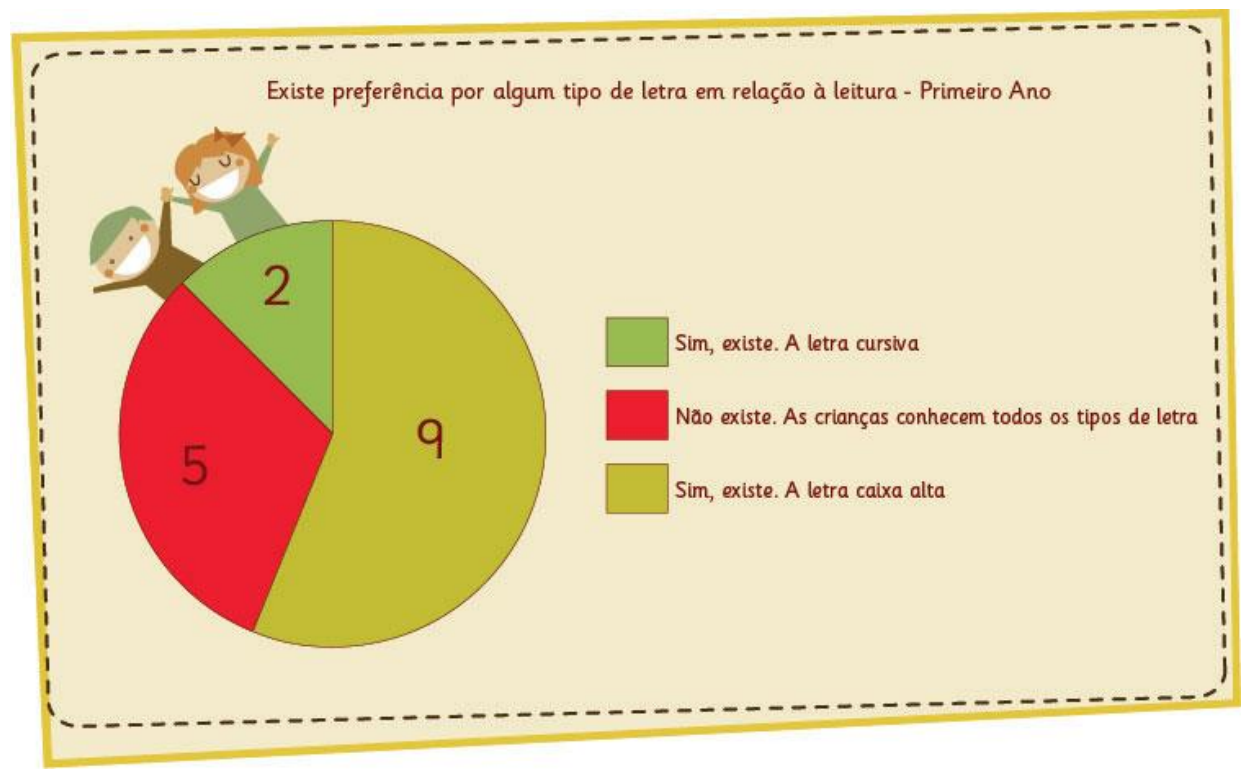

A maior parte dos professores aponta a predileção das crianças por algum tipo de letra, nove destacam a letra caixa alta e dois a letra cursiva. 
Pergunta 11 (segundo ano): Gráfico gerado (Figura 22).

Figura 22: Gráfico da pergunta onze, segundo ano. (Fonte: Lourenço)

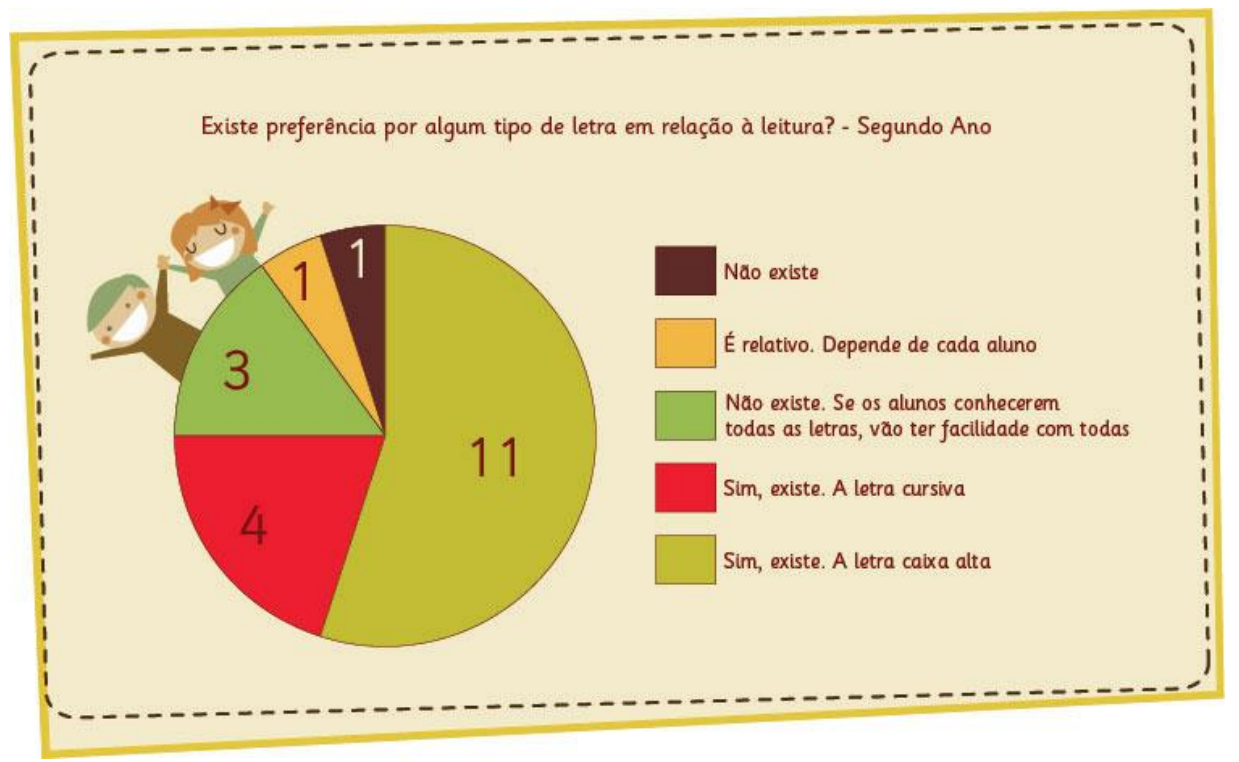

No segundo ano do ensino fundamental pode-se verificar que os professores destacam, em sua grande parte, a preferência das crianças pela letra caixa alta. Logo em seguida segue a letra cursiva.

\section{Considerações Finais}

Criar um método avaliativo referente à leitura de crianças em início de aprendizagem é uma tarefa complexa e envolve muitas variáveis. Muitos são os pesquisadores que criaram métodos avaliativos de legibilidade e leiturabilidade, todavia, não considera a escrita como parte integrante de um ato que envolve uma malha de conexões entre diversas variáveis durante o ato de leitura.

Como discutido anteriormente, $\mathrm{o}$ ato da escrita e da leitura, tanto pelos pesquisadores; Ferreiro \& Teberosky (1999), Fisher (2006), Cunha (2003), Bazerman (2007) quanto pelos professores pesquisados é indissociável em sua maior parte. Portanto, em novos testes de legibilidade e leiturabilidade devem-se considerar a importância de se associar a escrita com a leitura.

A aplicação de questionários para os professores do primeiro e do segundo ano de escolas do ensino fundamental foi necessária e fundamental para se desvendar aspectos relacionados à leitura, como o fato de que o reconhecimento de certos tipos de caracteres surge com o tempo e com a prática, que as crianças apresentam suas preferências em relação ao tipo de letra e que a aprendizagem da leitura continua a se desenvolver no segundo ano.

\section{Referências}

BRANDÃO, A. C. \& Spinillo, A. G.(1998). Aspectos gerais e específicos na compreensão de textos. Psicologia: Reflexão e Crítica, 11 (2), 253-272.

CUNHA, U. (2010). Leitura E Escrita No Ensino Fundamental, (Res) Significando O Trabalho Com Gêneros Textuais. Práxis Educacional. V.6, n.8. Vitória da Conquista.

FISHER, S. R. (2006) História da Leitura. Tradução: Cláudia Freire. São Paulo: Editora UNESP. 
FRASCARA, J. (2003) Optometry, legibility and readability in information design. Select Readings of the Information Design International Conference. SBDI/ The Brazilian Society of Information Design.

FERREIRO, E.\& TEBEROSKY, A. (1999). Psicogênese da Língua Escrita. 4ª ed. Porto Alegre: Artes Médicas.

ROCCO, M. T. (1996). Leitura e escrita na escola: algumas propostas. Em Aberto, Brasília, ano 16, n.69, jan./mar.

SASSOON, R. \& WILLIAMS, A. (2000). Why sasson? Artigo completo.

SASSOON, R.(1993). Through the eyes of a child: perception and type design. In R. Sassoon (ed) Computers and typography. Oxford: Intellect Books, pp.150-77.

WALKER \& REYNOLDS (2003). Serifs, sans serifs and infant characters in children's reading books. Information Design Journal 11, 2/3, pp.106-22.Ano:2003.

\section{Sobre os autores}

Daniel A. Lourenço. Doutorando em Design da UFPE. Professor do curso Superior de Tecnologia em Design Gráfico no IFPB. <lourencodesign@gmail.com.br>

Solange Galvão Coutinho; PhD, UFPE; <solangecoutinho@globo.com> 